\title{
SOFTWARE FOR THE SEVENTIES
}

\section{Renee Sherrow}

Let's install a lab! Nothing can go wrong! It was the decade of the sixties: a golden era. Language institutes flourished, electronic labs sprouted, magnetic tapes proliferated, and Candide-like optimism prevailed throughout the land. Surely, labs could help solve many of the problems facing language educators. The sixties, however, often proved to be a golden error. Language labs caused at least as many problems as they solved, and teachers discovered, contrary to expectations, that almost nothing could go right in lab.

The litany of problems is only too well known. First, it is not unusual to have more students than there are lab stations in good working order. Second, many tape programs produce hypnosis more successfully than they do good language habits. Third, students who are not comatose in lab are either doing homework for other classes, attacking their neighbors, or sabotaging the equipment-secure in knowing that the teacher cannot see behind the partitioned booths. It is small wonder, then, that so many language labs have been abandoned or transformed into highly uncomfortable and prohibitively expensive teaching classrooms.

In evaluating the successes-and more often the failure-of typical language lab programs, it seems that part of the problem results from poorly defined goals. Labs were installed for the wrong reasons.

During the sixties, schools purchased language labs so that real, native voices could be introduced into the classroom. Assuming that these native voices, speaking at rormal. conversation speed, can be understood, a tape recorder in class is quite sufficient for this purpose. The installation of an entire lab, however, is not justified.

Language labs were supposed to produce students with near native pronunciation. The past decade has shown that repetition after native models does not necessarily guarantee this result. Students do not always correct their errors assuming first, that they perceive them, second, that they know how to correct them, and third, that they want to correct them. A live teacher who can accept or reject student pronunciation and offer individual guidance is a vital part of a successful lab program.

*Text of an address given March 20,1970 at the Boston section of the Northeast Conference on Teaching. 
Another selling point was that lab tapes would free teachers to give help to individual students. This is a fallacy. One need not be a whiz at math to figure out that one teacher facing thirty students in a thirty-minute lab period has the same amount of time to allot each individual as does one teacher facing thirty students in a thirtyminute class period. In fact, it could be argued that less individualized help is possible in lab, if ore considers the time lost in changing classrooms and putting on tapes.

In the sixties, there was hope that orally manipulated patterns would teach students to speak fluently. This hope never materialized. More often than not, students failed to span the enormous gap between controlled utterances in response to taped cues and unstruc. tured conversation in response to personal desires for expression.

In order that labs may fulfill their very real promise, a thorough re-evaluation of ways in which labs are currently employed is needed. It is also necessary to rethink what qualities constitute an effective tape program. While lab hardware is often impressive, the software of lab scheduling and lab materials are but primitively developed. These two areas will be the major concerns of this paper.

In redefining goals for the seventies, two exciting possibilities are using the lab for individualizing instruction and teaching for mastery. This cannot be accomplished, however, with present scheduling practices.

Assigning entire classes for twenty to thirty minutes of lab practice once or twice a week is pedagogically unsound. It is difficult for teachers to plan around such a fixed schedule which an assembly, a snow day, or a fire drill can so easily upset. Moreover, in view of the great number of hours needed to attain some degree of foreign language proficiency, it is hard to justify allotting the equivalent of one (or more) out of five teaching days for lab practice and review. Finally, the time lapse between class presentation and lab practice is detrimental to effective learning.

Some alternative proposals are in order. One possibility is scheduling students into language lab instead of a study hall. Students with no free periods can be accommodated before or after regular school hours. Assignments to be completed in lab and later checked by the teacher should be part of a student's regular homework. If language teachers indeed claim to teach all four skills, then it does not make sense to give homework assignments requiring reading and writing, but never listening and speaking. It is not reasonable to expect students to develop audio-lingual skills if those skills are not accorded the same importance as reading and writing.

A second possibility is to equip each language room as an elec- 


\section{Softwear for the Seventies}

tronic classroom. This would permit the teacher to use practice tapes whenever they fit naturally into the teaching sequence. It would also eliminate time being lost changing classrooms as well as time lapsing between presentation and practice of new material.

Both the study hall and the electronic classroom lend themselves well to individualized instruction. It must be noted, however, that meaningful individualization cannot be accomplished unless additional personnel are available to reduce the teacher-student ratio.

Team teaching is a requisite of programs which seriously intend to individualize instruction. Teacher aids could be in charge of nonlanguage responsibilities such as checking lab attendance, playing tapes and maintaining equipment. Capable undergraduate language majors, teaching interns, or native speakers residing in the community might supplement the regular classroom teacher. They could supervise students in lab, offer extra help to students having difficulty, and conduct small conversation groups. Highly trained professional language teachers should be freed from policing corridors and study halls so that they can teach. Too many years of language study and professional training go to waste when teachers become clerks and monitors.

In a team teaching situation, the role of the classroom instructor is broadened. Rather than serving only as a source of information and knowledge, he is also the coordinator and manager of the individualized teaching schedule. He decides which activities would be most appropriate for each learner. Team teaching offers the responsibility of adequate lab supervision. In order for students to be active in lab, there must be a teacher active in lab. Supervision is a necessity, for if tape practice consists of overlearning errors, students actually suffer more from their lab experience than they profit from it.

Team teaching can enable part of a class to work with tapes while another part can practice free conversation in small groups. The importance of small group work - i.e. ten studnets or less - needs to be emphasized. Mere oral manipulation of taped patterns should not be called speaking. Actually, in order for pattern practice to contribute positively to a student's speaking ability, the patterns must be transferred and used in a relatively unstructured conversation setting.

Co-ordinating a flexible laboratory program with team teaching is but a first step. The most ingenious schedule will accomplish little if the lab materials themselves are ineffective. Given the soporific nature of many commercial tapes, it is small wonder that students and lab practice have gone the way of oil and water.

Some tapes for beginners present dialogues at a speed so rapid that all but the most capable students feel lost. Even realistic sound effects and musical interludes fail to maintain interest in what simply 
cannot be understood. Sink-or-swim natural speed on beginning tapes cannot be justified since too many students opt for the first alternative.

A rule which has traditionally governed the use of lab tapes has been, "Students should practice in lab only material which has previously been taught in class." What better formula can possibly be prescribed for guaranteed instant boredom? While it is advisable that new material be taught only by a teacher, lab tapes need not and indeed should not - consist solely of the same material presented in class. Rather, lab tapes should vary and recombine the structure and vocabulary taught in class.

Not only would new and different exercises add interest to lab practice, they would also develop the students' ability to comprehend and speak in semi-familiar language contexts. It would accustom them to apply their knowledge to new situations. They would actually have to think - a startling, revolutionary innovation after an era of bored, mechanistic parrotting.

The rule that labs should be used for overlearning has also had a pernicious influence on some textbooks. It has created a tail-wagging situation in which some textbooks consist merely of tape scripts glorified by pictures, homework exercises, and grammar explanations. The function of a text is to present new material clearly. The function of a tape is to apply this material in new situations. These two disparate functions should not logically be fulfilled by the same material for it is detrimental to language learning. For example, students will not develop auditory skill if they merely read the answers to tape drills in their textbooks.

Tapes should not be used with textbooks. They should be coordinated with workbooks. Happily, some progress has been made in this direction. Some new workbooks provide answer grids for sound discrimination and listening comprehension exercises. However, more needs to be accomplished in this area. Workbooks could also be useful for fill-in-the blank spelling and dictation practice. Workbook pictures could serve as the basis for answering tape questions. Pictures could provide a real, meaningful context to which students can refer. This is infinitely preferable to having students manipulate abstract patterns according to arbitrary directions.

Though a basic tenet of language methodology prescribes a variety of activities during a forty-minute class session, this principle has been grossly ignored on professionally prepared tapes. A tape presentation can, however, with a little imagination, offer numerous varied activities: sound discrimination exercises, listening comprehension drills, pattern practice within meaningful contexts, questions to answer based on workbook pictures, dialogs with questions afterwards, and spelling or dictation practice. It is important to provide students 


\section{Softwear for the Seventies}

with opportunities to write in lab, to relieve the monotony of constant listening and speaking.

One possibility which has not been sufficiently developed is having the tape speaker review briefly the principles which the student will need in order to complete the exercises successfully. There might be a brief review of structure rules, or the students' attention might be directed to the correct pronunciation of difficult sounds. In addition to adding variety to the tape program, this pre-drill explanation is an effective teaching device since it comes at a pedagogical moment of grace when the student is unusually receptive to instruction.

Looking beyond language lab tapes as they are known today, tape cassettes seem to offer unique opportunities for future attempts at individualizing instruction and teaching for mastery. Conceivably, the tape program for each unit could be recorded on ten-minute cassettes. When students complete one segment, they can elect to hear it again or to go on to the next segment. Under this system, whole classes need no longer be locked into following one tape at one speed. The flexibility of tape cassettes would permit students to proceed at their own pace. A student need not advance to the next step before he has mastered the one before it.

In addition to their greater flexibility, cassettes have the advantage of being simple, idiot-proof, and nearly indestructible. Furthermore, the few seconds which may elapse between the playing of successive cartridges can give students a needed chance to relax so that they will maintain their attention on subsequent exercises.

The following is a tape script which illustrates some of the principles already mentioned. Activity I. Listening. Turn to page 25 in your workbook. You have learned 3 irregular verbs: etre, to be, aller, to go, and avoir to have. Can you tell which verb you hear in a sentence? For example, "Ils sont en classe", means "they are in class." "Ils vont en classe," means, "they are going to class." "Ils ont une classe," means "they have a class." Small sound differences can make big differences of meaning in French. You will hear 3 sentences. Each one will be repeated twice. Check if the verb you hear is a form of etre, aller, or avoir. Commencons.

1. Elles sont au restaurant pres de l'ecole. Elles sont au restaurant pres de l'ecole. \#

2. Le jeudi ils ne vont jamais au musee. Le jeudi ils ne vont jamais au musee. \#

3.Ils ont un restaurant pres d'ici. Ils ont un restaurant pres d'ici. \# Now check your answers. 
1. Elles sont au restaurant près de l'école. être.

2. Le jeudi, ils ne vont jamais au musée.

alle:

3. Ils ont un restaurant près d'ici. avoir.

Activity II. Listening and Speaking. You will hear people tell you where they live or where they work. Can you guess if their nationality is French, American, or Canadian? Usc a màsculine adjective if the speaker is a man and a feminine adjective if the speaker is a woman. For example, you hear, "J'habite Paris." You answer, "Vous êtes française," because you heard a woman from Paris talking. You will hear each item twice. Commencons. Ecoutez et répondez.

1. Nous habitons Québec et nous parlons toujours français. Nous habitons Quebec et nous parlons toujours français. \#Vous êtes canadiennes. \#Vous êtes canadiennes.

2. Je travaille pour M. Durand, 77 rue Coty, a Fort-de-France. Je travaille pour M. Durand, 77 rue Coty, a Fort-de-France. \#Vous êtes français. \#Vous êtes français.

3. J'habite New York et je travaille à Wall Street. J'habite New York et je travaille à Wall Street. \#Vous êtes americaine. \#Vous êtes americainc.

Activity III. Speaking. Pretend you are interviewing a friend for the school newspaper. As you write down the information she gives you, repeat what she says to make sure the facts are right. For example, you hear, "Il ya cinq personnes dans ma Famille." You answer, "Il y a cinq personnes dans ta famille." You will hear each item twice Commencons. Ecoutez et répondez.

1. Mes amies et moi, nous aimons le français. Mes amies et moi, nous aimons le franģais. \#Tes amies et toi, vous aimez le français. \#Tes amies et toi, vous aimez le français.

2. Ma mère et mon père parlent français à la maison. Ma mère et mon pere parlent français a la maison. \#Ta mere et ton pere parlent français à la maison. \#Ta mère et ton père parlent français a la maison.

3. Je vais en France avec mon amie Helene. Je vais en France avec mon amie Helene. Tu vas en France avec ton amie Helene. Tu vas en France avec ton amie Helene.

Activity IV. Speaking. Turn to page 26 in your workbook. Mr. Durand is visiting a friend he has not seen in many years. He enjoys showing 


\section{Softwear for the Seventies}

him wallet pictures of his two sons, his daughter, and his house. Pretend you are Mr. Durand and explain the pictures in your workbook in response to your friend's questions. For example, your friend asks, "Qui est-ce?" You answer, "C'est ma famille." You will hear each question twice. Commençons. Ecoutez et répondez.

1. Qui sont les deux garçons? Qui sont les deux garçors? \#Ce sont mes fils. \#Ce sont mes fils.

2. Et la jolie jeune fille? Et la jolie jeune fille? \#Cest ma fille. \#C'est ma fille.

3. Qu'est-ce que c'est? Qu'est-ce que c'est? \#C'est ma maison. \#C'est ma maison.

Activity V. Conversations and questions. You will hear a brief conversation, some questions afterwards, then the conversation a second time. Some words you hear may be unfamiliar to you. Try to guess what they mean. Even if they are too hard, do not be upset. You should still understand enough to answer the questions. Commencons. Ecoutez:

Marianne is not anxious to tell Andre where she lives.

André: Où est-ce que tu habites, Marianne?

Marianne: J'habite Paris.

André: Bien sôr, mais quelle rue est-ce que tu habites?

Marianne: (pause) Euh . . . rue Laporte.

André: Rue Laporte? Magnifique! C'est pres d'ici. Et a quel numero est-ce que tu habites?

Marianne: (mumbled)

Andre: Comment?

Marianne: (sigh) au cent cinq.

Questions. Ecoutez.

1. Quelle ville est-ce que Marianne habite?

2. Quelle rue est-ce qu'elle habite?

3. A quel numero habite-t-elle?

In conclusion, it should be emphasized that in spite of the things which went wrong in the sixties, language laboratories can play a vital role in the language curriculum. If sophisticated hardware equipment - can be coupled with sophisticated software - intelligent scheduling and interesting tapes - then there is indeed great potential in employing the language lab as a means for individualizing instruction and teaching for mastery. In the seventies, let us continue our lab programs. This time, let us make things go right!

ABOUT THE AUTHOR:

Miss Sherrow is a teacher of French at Valley Stream, New York. 